\title{
Pneumatocele or something more?
}

\author{
Joana Teixeira, ${ }^{1}$ Tomás Silva, ${ }^{1}$ Jorge Correia-Pinto, ${ }^{1,2}$ Augusta Gonçalves ${ }^{1}$
}

${ }^{1}$ Hospital de Braga, Braga, Portugal

${ }^{2}$ University of Minho, Braga, Portugal

\section{Correspondence to} Dr Joana Teixeira, jiteixeira@hotmail.com

Accepted 18 December 2015

\section{DESCRIPTION}

A 2-year-old girl was referred to our paediatric pulmonary consultation due to recurrent pneumonia and residual pneumatocele. The child was born at 32 weeks of gestation by emergency caesarean delivery due to a maternal cause. No evidence of congenital malformation was found on prenatal ultrasounds.

From 9 months of age, the child had had three bouts of pneumonia, all in the same location (right lung base). Thoracic radiography showed a hypertransparent ovoid area after pneumonia resolution (figure 1). Chest CT scan revealed multiple small intraparenchymal cavitations suggesting pneumatoceles. Bronchoscopy was unremarkable. The child remained asymptomatic between episodes.

At 28 months of age, the child was diagnosed as having a new episode of pneumonia in the same location. Repeated CT raised the hypothesis of a congenital pulmonary airway malformation (CPAM) (figure 2), and she was submitted to a thoracoscopic right inferior lobectomy. Diagnosis of type 1 CPAM was confirmed by pathology.

In the first months of life, structural or functional airway anomalies may present as multiple pneumonias of the same lung lobe. Three major differential diagnoses are cystic fibrosis, primary ciliary dyskinesia and primary immunodeficiencies.

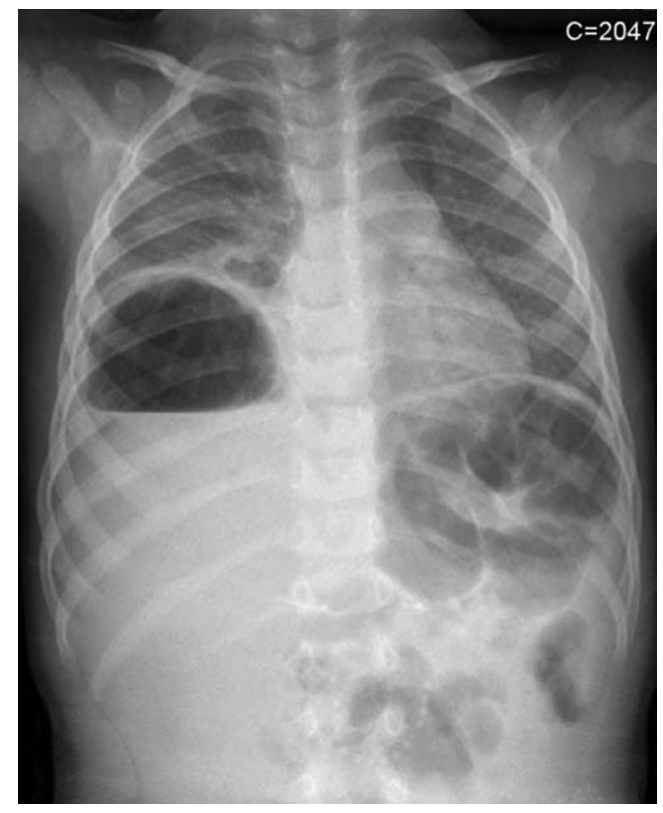

Figure 1 Hypertransparent ovoid area in the right lung base.

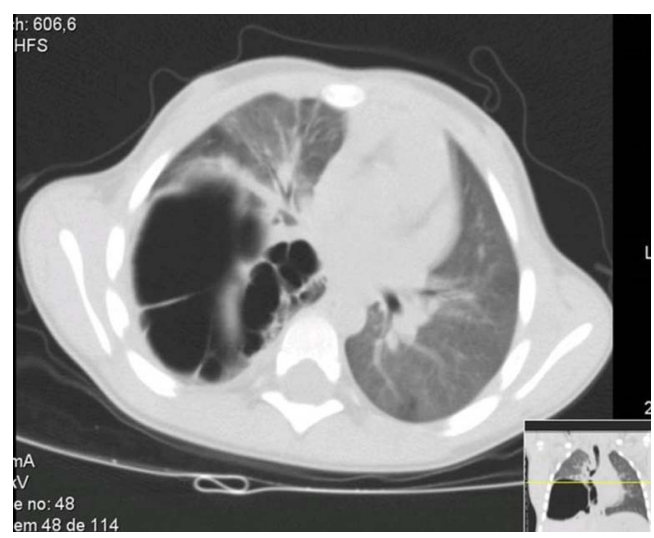

Figure 2 Multicystic massive lesion occupying virtually the entire right lower lobe, with a dominant $8.6 \mathrm{~cm}$ cyst.

As opposed to CPAM, these usually lead to generalised pneumonia. CPAM is a rare developmental anomaly of the lower respiratory tract. ${ }^{1}$ Type 1 CPAM is the most common form, comprising 60 $70 \%$ of cases. The widespread use of antenatal ultrasound examination has resulted in an increase in prenatal CPAM diagnosis. Nevertheless, about one-third of cases are diagnosed after the neonatal period, as in this case. ${ }^{12}$ The most common presentation is recurrent pneumonia, where diagnosis requires a large index of suspicion.

\section{Learning points}

- Congenital pulmonary airway malformations (CPAM) may be suspected if recurrent pneumonia affects the same lung lobe.

- Early thoracoscopic resection of the affected pulmonary lobes with CPAM is recommended to avoid recurrent pneumonia.

Competing interests None declared.

Patient consent Obtained.

Provenance and peer review Not commissioned; externally peer reviewed.

\section{REFERENCES}

1 Bolde S, Pudale S, Pandit G, et al. Congenital pulmonary airway malformation: a report of two cases. World I Clin Cases 2015;3:470-3.

2 Zhuo $\mathrm{L}$, Ren $\mathrm{L}$, Liu $\mathrm{Q}$, et al. Death from bilateral pulmonary congenital cystic adenomatoid malformation: a rare case report. Am J Forensic Med Pathol 2011;32:25-7. 
Copyright 2016 BMJ Publishing Group. All rights reserved. For permission to reuse any of this content visit http://group.bmj.com/group/rights-licensing/permissions.

BMJ Case Report Fellows may re-use this article for personal use and teaching without any further permission.

Become a Fellow of BMJ Case Reports today and you can:

- Submit as many cases as you like

- Enjoy fast sympathetic peer review and rapid publication of accepted articles

- Access all the published articles

- Re-use any of the published material for personal use and teaching without further permission

For information on Institutional Fellowships contact consortiasales@bmjgroup.com

Visit casereports.bmj.com for more articles like this and to become a Fellow 